\title{
TINJAUAN FORMAT IDEAL, FUNGSI DAN ESTETIKA BULETIN BINUS UNIVERSITY
}

\author{
Sari Wulandari \\ Jurusan Desain Komunikasi Visual, Fakultas Komunikasi dan Multimedia, BINUS University \\ Jln. K.H. Syahdan No. 9, Kemanggisan, Palmerah, Jakarta Barat 11480 \\ swulandari@binus.edu
}

\begin{abstract}
Buletin BINUS is a communication medium that connects Binusian, contains information about events held at BINUS. Figures of this bulletin is BINUS University, either through the appearance and content of the newsletter itself, where the messages contained in explicit and implicit so that eventually will form a picture or image in the mind of the reader. This study examines the function and aesthetics in a format specific BULETIN which was published in 2008 and 2009. Reviewes carried out refers to the disciplines of Visual Communication Design. The purpose and benefits of this research is to use scientific and practical layout Buletin BINUS University and research results in the form of suggestions are ideal application of design elements for publication Buletin BINUS University, which is based on ease of implementation, the function of information, the effectiveness of media communications, and aesthetics. It is expected that the information in it will be delivered properly, can bring out the character right BINUS University and establish a positive image in the mind of the reader.
\end{abstract}

Keywords: bulletin, media, function, aesthetic, image, communication

\begin{abstract}
ABSTRAK
Buletin BINUS merupakan sebuah media komunikasi yang menghubungkan BINUS dengan para Binusian, berisi informasi mengenai kegiatan-kegiatan baik yang diselenggarakan di lingkungan BINUS. Buletin ini mewakili sosok BINUS University, baik melalui tampilan perwajahan maupun isi dari Buletin itu sendiri, di mana pesan yang tercantum di dalamnya selain merupakan pesan secara tersurat dan juga tersirat sehingga akhirnya akan terbentuk citra atau imaji di dalam benak pembacanya. Penelitian ini meninjau format fungsi dan estetika pada Buletin khususnya yang diterbitkan pada tahun 2008 dan 2009. Tinjauan dilakukan mengacu pada dispilin ilmu Desain Komunikasi Visual. Tujuan dan Manfaat dari penelitian ini antara lain memanfaatkan keilmuan dan praktis tentang tata letak Buletin BINUS University dan keluaran hasil penelitian berupa usulan ideal penerapan elemen-elemen desain untuk publikasi Buletin BINUS University, yang didasarkan pada kemudahan penerapan, fungsi informasi, efektivitas media komunikasi, dan estetika. Dengan demikian diharapkan informasi yang ada di dalamnya akan dapat tersampaikan dengan baik, dapat memunculkan karakter BINUS University secara tepat dan terbentuk citra positif dalam benak pembacanya.
\end{abstract}

Kata kunci: buletin, media, fungsi, estetika, imaji, komunikasi 


\section{PENDAHULUAN}

Informasi merupakan kebutuhan manusia. Tanpa informasi manusia akan tersesat. Begitu pula sebaliknya, terlalu banyak informasi pun ketersesatan juga dapat terjadi. Melalui porsi eksposur yang tepat maka sebuah informasi akan dapat diserap dengan baik, membawa manfaat dan akhirnya dapat menuntun manusia ke arah yang lebih baik. BINUS University memiliki media komunikasi dan informasi yang bersifat internal bagi para Binusian, berupa Buletin yang terbit satu bulan sekali,berisi beberapa rubrik tetap, beragam artikel-artikel dan informasi ringan. Melalui Buletin ini diharapkan dapat menjadi jembatan komunikasi dan media sapa antara BINUS University sebagai pemberi pesan dengan Binusian sebagai penerima pesan.

Penelitian ini meninjau format fungsi dan estetika pada buletin khususnya yang diterbitkan pada tahun 2008 dan 2009. Tinjauan dilakukan mengacu pada dispilin ilmu Desain Komunikasi Visual. Secara garis besar format yang ada menunjukkan banyak kelemahan sehingga pesan yang disampaikan baik secara langsung (tersurat) maupun tidak langsung (tersirat) tidak dapat membantu terbentuknya citra atau imaji BINUS University di dalam benak pembacanya. Untuk itu perlu adanya pengaturan pada tata letak yang menyangkut tipografi, warna, tekstur, gambar dan elemen-elemen desain lainnya, mengingat isi yang disampaikan cukup banyak pada ruang yang terbatas.

Beberapa hal baik yang perlu dipertahankan yaitu kreativitas dalam pengembangan visual, di mana tata letak tampil cukup variatif sehingga dapat mencegah kebosanan. Namun hal ini perlu diimbangi dengan menjaga kestabilan nuansa pada visual sehingga karakter BINUS University dapat tampil dan terjaga dengan baik. Hasil penelitian ini diharapkan menjadi saran/usulan ideal penerapan elemen-elemen desain untuk publikasi buletin, yang didasarkan pada kemudahan penerapan, fungsi informasi, efektivitas media komunikasi, dan estetika dalam bentuk Panduan Praktis yang dapat digunakan sebagai rujukan oleh pihak pengelola Buletin BINUS University sehingga dapat mencapai tampilan yang optimal serta mendukung terciptanya karakter dan pencitraan BINUS University secara tepat.

Tujuan dan manfaat dari penelitian ini antara lain: Studi keilmuan dan praktis tentang tata letak Buletin BINUS University, data dan evaluasi tentang Buletin BINUS University yang telah ada di lingkungan kampus, manfaat penelitian berupa saran/usulan ideal penerapan elemen-elemen desain untuk publikasi Buletin BINUS University, yang didasarkan pada kemudahan penerapan, fungsi informasi, efektivitas media komunikasi, dan estetika, produk akhirnya adalah Panduan Praktis yang dapat digunakan sebagai rujukan oleh pihak yang mengelola Buletin BINUS University.

Buletin merupakan media yang menyerupai majalah namun lingkup distribusinya terbatas pada kalangan tertentu dan dibagikan secara cuma-cuma. Topik yang disajikan pada artikel terbatas pada ruang lingkup dimana Buletin tersebut beredar. Berbeda dengan majalah di mana berisi bermacam-macam artikel dalam subyek yang bervariasi dengan topik populer yang ditujukan kepada masyarakat umum dan ditulis dengan gaya bahasa yang mudah dimengerti oleh banyak orang. Berbeda dengan Buletin di mana distribusikan untuk kalangan tertentu, maka penyampaian pesan menggunakan gaya bahasa yang sesuai dengan profil pembacanya. Majalah biasa diterbitkan mingguan, dwimingguan atau bulanan, sedangkan buletin pada umumnya diterbitkan satu bulan sekali.

Sejarah BINUS University dimulai dari Modern Computer Course/ MCC tahun 1974, kemudian berevolusi berturut-turut menjadi Akademi Teknik Komputer tahun 1981, Akademi Manajemen Informatika dan komputer tahun 1984, STMIK tahun 1987, BNTRC tahun 1991, membuka program Magister Manajemen tahun 1993, dan menjadi Universitas Bina Nusantara pada tahun 1996. Berbagai prestasi telah diraih, demi meningkatkan mutu BINUS mengadopsi sistem ISO dan melebarkan sayap dengan membuka penyelenggaraan pendidikan dari tingkat dasar BINUS 
School hingga tingkat lanjut Program Magister Management BINUS School of Business, BINUS International dan juga kursus BINUS Center yang berkembang hampir di seluruh kota besar di Indonesia.

BINUS memiliki visi BINUS Vision 20/20: A World-class university in continuous pursuit of innovation and enterprise. BINUS mengupayakan lulusannya agar dapat diterima di pasar serta lingkungan global melalui pendidikan tinggi yang diarahkan pada proses belajar mengajar dan penelitian. Misi BINUS yaitu: commits to deliver excellence in education and research for the global community by Providing a learning experience that encourage and rewards innovation, creating high impact applied knowledge, pursuing a positive contribution to the quality of life, contributing to outstanding leadership, leading corporate enterepreneurship.

Buletin BINUS dipublikasikan oleh Direktorat Marketing Communication BINUS, merupakan sebuah media komunikasi yang menghubungkan antara BINUS dengan para Binusian di seluruh unit dan center di lingkungan BINUS. Diterbitkan satu bulan sekali, didistribusikan dengan cara konvensional (berupa barang cetakan) maupun dengan menggunakan media internet (dalam format pdf). Kehadiran Buletin BINUS di hadapan Binusian adalah mewakili sosok BINUS University, baik melalui tampilan perwajahan maupun isi dari Buletin itu sendiri, di mana pesan yang tercantum di dalamnya selain merupakan pesan secara langsung (tersurat) dan juga tidak langsung (tersirat) sehingga akhirnya akan terbentuk citra atau imaji di dalam benak pembacanya.

Isi Buletin BINUS adalah informasi mengenai kegiatan-kegiatan baik yang diselenggarakan di lingkungan BINUS maupun di luar BINUS dimana Binusian terlibat dalam kegiatan tersebut, tips-tips, profil Binusian, artikel, informasi merchant, informasi yang bersifat pemberitahuan (kelahiran, duka cita, prestasi, penghargaan, dan lain-lain) serta iklan dari para sponsor.

Pada cover ditampilkan bidang logo BINUS University dengan blok warna biru serta elemen grafis simbolisasi air. Nameplate BULETIN ditulis dengan cara all capital, menggunakan huruf korporat BINUS University dengan modifikasi pada titik di huruf 'i'. Di dalamnya terdapat rubrik tetap yaitu: Rector Speak, What's Going On?, IT Corner, Binusian Profile, BEC, Merchant, Inspirasiku Inspirasimu. Disini digunakan elemen-elemen grafis untuk mendukung estetika namun dalam pemilihan elemen grafis kurang dapat mendukung terbentuknya pencitraan BINUS University yang tepat, mengacu kepada visi dan misi BINUS University.

Buletin BINUS memiliki spesifikasi teknis yaitu ukuran $20 \mathrm{~cm} \mathrm{X} 28 \mathrm{~cm}$, jumlah halaman sebanyak 32 halaman termasuk cover, cetak offset, full color, penjilidan dengan cara jilid jahit kawat. Buletin ini memiliki target pembaca dengan profil demografi berusia18 - 50 tahun, pria dan wanita, dengan status mahasiswa, dosen dan karyawan BINUS University dan status ekonomi sosial B-C, serta psikografis senang mempelajari hal-hal baru dan informasi terbaru, punya motivasi untuk maju dan meningkatkan prestasi serta ktif dalam kegiatan-kegiatan di lingkungan kampus BINUS. Berikut ini adalah gambar-gambar tampilan visual Buletin BINUS University.
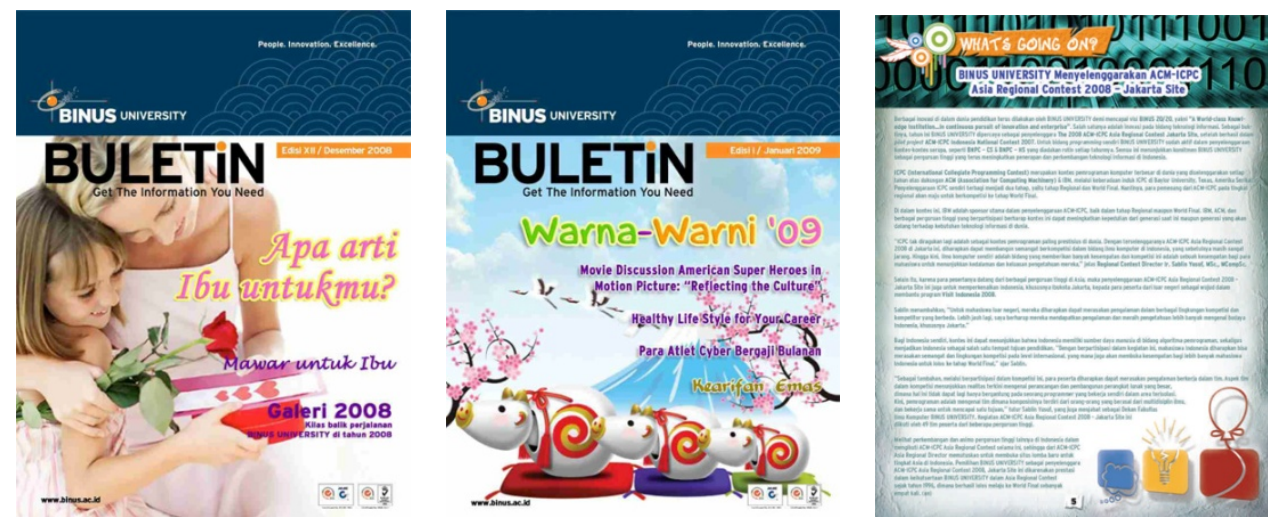

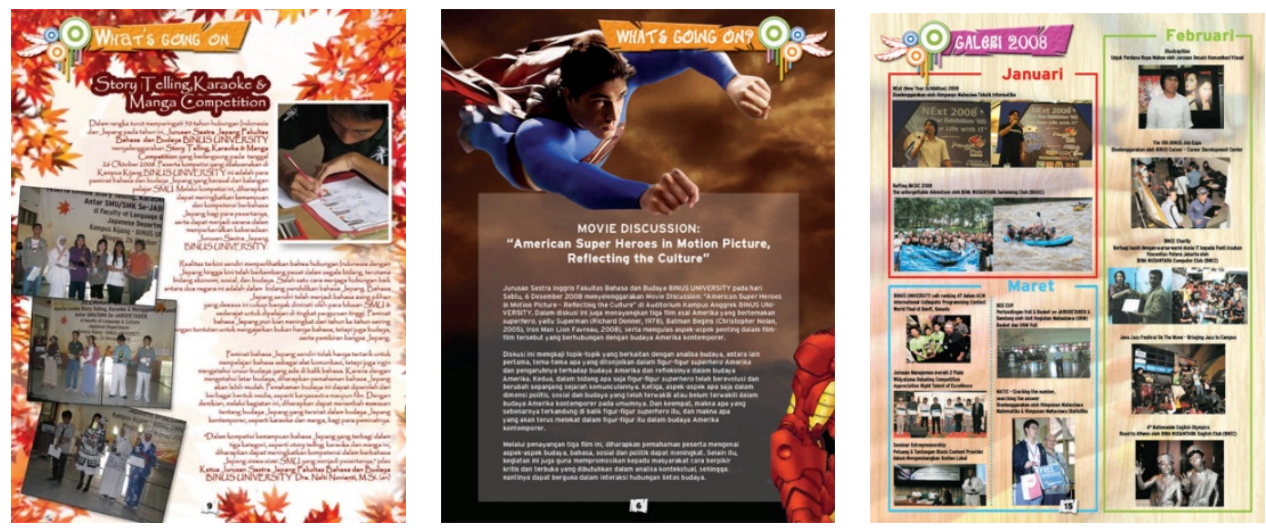

Gambar 1 Contoh-contoh isi dan cover Buletin BINUS

Di dalam sebuah editorial berisi pesan yang hendak disampaikan. Pesan ini dapat bersifat persuasif, informatif atau pun provokatif baik dalam jumlah yang panjang maupun singkat.Untuk itu seorang desainer selain perlu memahami cara penyampaian pesan sesuai sifatnya, juga perlu mengetahui prioritas pembaca dalam mengakses pesan-pesan tersebut. Perlakuan satu paragraf terhadap paragraf lain dapat dibedakan sesuai kebutuhan tersebut. Hal ini sangat membantu pembaca dalam mengakses pesan secara mudah dan nyaman sehingga baik pesan tersurat maupun tersirat dapat ditangkap dengan tepat.

\section{METODE}

Metode yang akan digunakan dalam penelitian ini adalah metodologi observasi dan partisipatif dengan melakukan pengamatan dan pendataan atas media Buletin yang ada saat ini di lapangan. Melakukan kuesioner yang berkaitan dengan media tersebut kepada sekelompok Binusian, studi kepustakaan dengan melakukan riset pustaka pada perpustakaan BINUS University, topik media publikasi, format dan layout, tipografi, warna, magazine; dan wawancara nara sumber terkait, yaitu wawancara dengan pihak CMC (Corporate Marketing Communication) BINUS University untuk mengetahui sejauh mana jenis-jenis artikel yang akan dibuat yang nantinya akan dimasukkan ke dalam sistem, serta kepada sekelompok Binusian (terdiri dari karyawan, dosen lepas, dan mahasiswa) yang menjadi target pembaca dari Buletin, untuk mengetahui apa yang mereka dapatkan dan harapkan dari Buletin ini.

Setelah data diperoleh maka dibuatlah analisa data lapangan dan membandingkan dengan literatur teori ideal.kemudian dilakukan sintesa dengan mencari solusi kreatif melalui disiplin ilmu Desain Komunikasi Visual untuk kemudian disusun sebuah usulan berupa saran penyeragaman format, grid dan kolom.Hasil sintesa penelitian akan diterapkan dalam panduan yang dapat digunakan sebagai rujukan oleh pihak pengelola Buletin BINUS University agar dapat mencapai tampilan yang optimal sehingga informasi atau pesan yang disampaikan dapat diterima sepenuhnya, baik yang sifatnya tersurat maupun tersirat, didasarkan pada kemudahan penerapan, fungsi informasi, efektivitas media komunikasi, dan estetika, melalui penggunaan elemen-elemen desain yang dibakukan sehingga dapat membantu terbentuknya citra positif BINUS University.

\section{HASIL DAN PEMBAHASAN}

Melalui metodologi observasi dan partisipatif telah dilakukan pengamatan dan pendataan atas BULETIN BINUS terbitan 2008-2009 yang ada di lapangan dengan menyebarkan kuesioner kepada 
60 orang responden berusia18-50 tahun, pria dan wanita, mahasiswa, dosen dan karyawan BINUS University yang merupakan Binusian sebagai target pembaca, dengan hasil seperti pada Tabel 1.

Tabel 1 Hasil Kuesioner

\begin{tabular}{|c|c|c|c|}
\hline No & Pertanyaan & Jawaban & Prosentase \\
\hline \multirow[t]{3}{*}{1} & Pernah baca BB & Belum & $13 \%$ \\
\hline & & Kadang-kadang & $80 \%$ \\
\hline & & Sering & $7 \%$ \\
\hline \multirow[t]{3}{*}{2} & Cara mendapatkan BB & Akademis & $50 \%$ \\
\hline & & Teman & $20 \%$ \\
\hline & & Lainnya & $30 \%$ \\
\hline \multirow[t]{3}{*}{3} & Ketertarikan membaca BB & Tertarik & $20 \%$ \\
\hline & & Cukup & $63 \%$ \\
\hline & & Tidak & $17 \%$ \\
\hline \multirow[t]{3}{*}{4} & Desain Cover BB & Bagus & $13 \%$ \\
\hline & & Biasa & $80 \%$ \\
\hline & & Buruk & $7 \%$ \\
\hline \multirow[t]{3}{*}{5} & Desain Isi BB & Bagus & $17 \%$ \\
\hline & & Biasa & $70 \%$ \\
\hline & & Buruk & $13 \%$ \\
\hline \multirow[t]{3}{*}{6} & Saran untuk BB ke depan & Lebih tebal isinya & $60 \%$ \\
\hline & & Lebih bagus desainnya & $27 \%$ \\
\hline & & Lainnya & $13 \%$ \\
\hline
\end{tabular}

Selain pada wawancara yang dilakukan, dapat disimpulkan bahwa target pembaca akan mengakses informasi pada BULETIN BINUS apabila: (1) tampilan menarik, (2) mudah didapat, (3) informasi nyaman untuk dibaca, (4) informasi menarik untuk diketahui. Berdasarkan kesimpulan di atas, hal yang dapat diselesaikan melalui disiplin ilmu Desain Komunikasi Visual adalah poin 1 yaitu tampilan yang menarik, serta poin 3 yaitu informasi nyaman untuk dibaca.

Melalui Studi Kepustakaan pada perpustakaan BINUS University, ditinjau dari sudut disiplin ilmu Desain Komunikasidengan topik seputar media publikasi, format dan layout, tipografi, warna, magazine disimpulkan bahwa masih banyak kelemahan pada tampilan visual Buletin BINUS yang disebabkan karena layout yang kurang diolah dengan baik sehingga tampilan kurang menarik untuk dibaca, tidak nyaman untuk dibaca sehingga informasi sulit ditangkap.

Pembahasan diawali dengan mengenali elemen layout editorial yang terdapat pada Buletin BINUS, baik pada halaman cover maupun pada halaman isi.

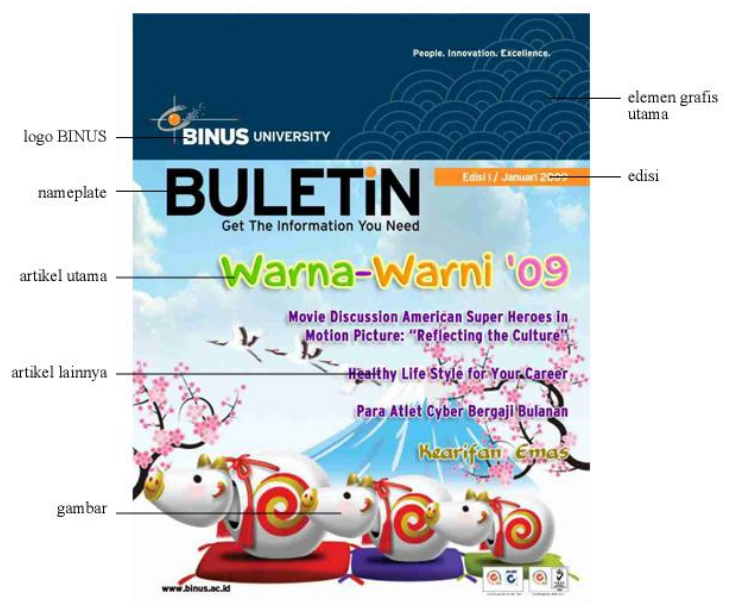

Skema di samping ini menunjukkan elemen-elemen layout editorial yang terdapat pada halaman cover BULETIN BINUS.

Gambar 2 Layout cover 


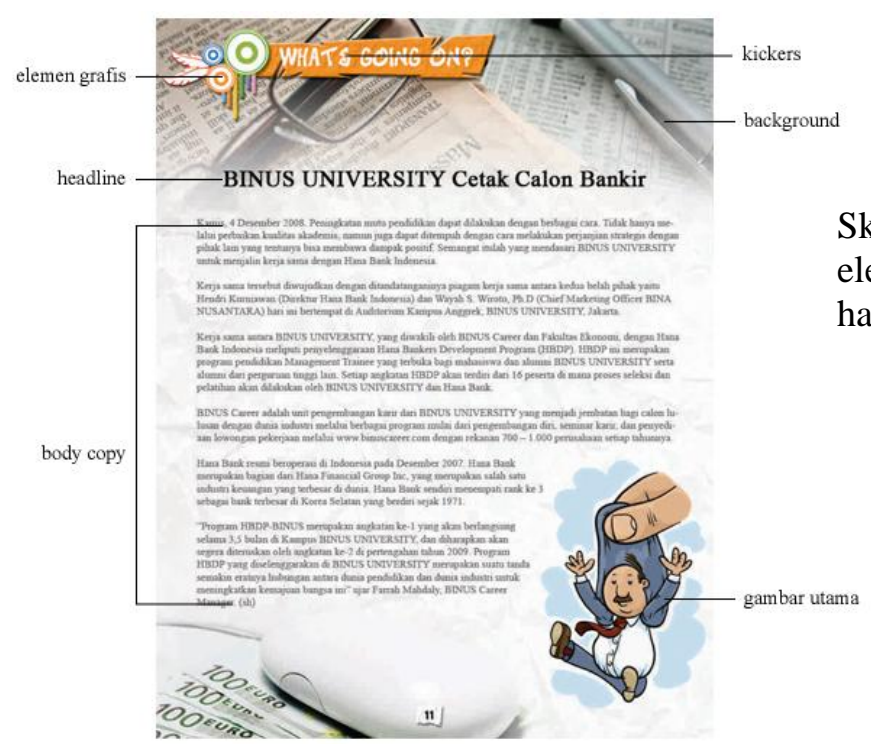

Skema di samping ini menunjukkan elemenelemen layout editorial yang terdapat pada halaman isi BULETIN BINUS.

Gambar 3 Layout Editorial

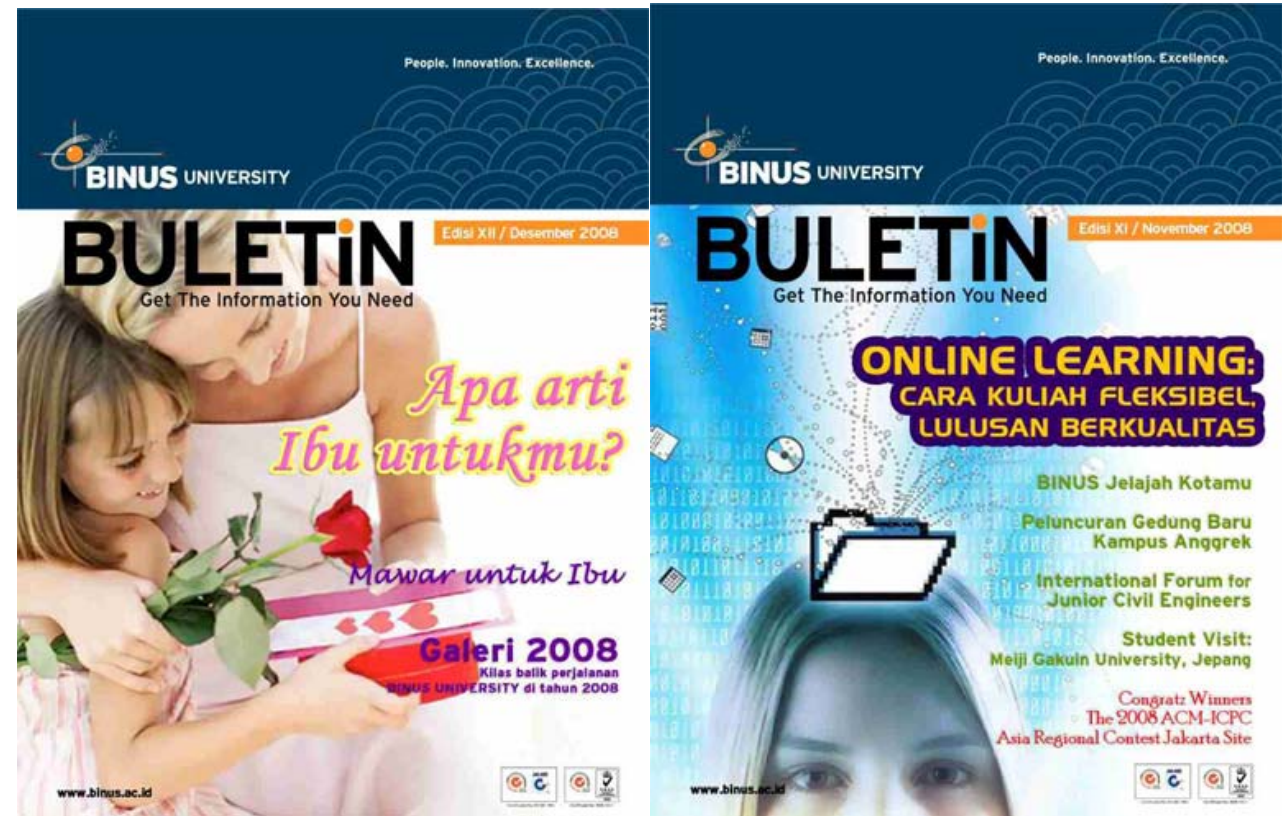

Gambar 4 Nameplate BULETIN BINUS

Nameplate BULETIN ditulis dengan cara all capital, menggunakan huruf korporat BINUS University dengan modifikasi pada titik di huruf 'i' di mana hal ini memberi kesan teknis, kaku dan tidak menimbulkan jalinan keterikatan emosi antara BINUS kepada pembacanya. Penempatan nameplate terlalu dekat dengan elemen visual lain bahkan di atas gambar yang cenderung berkompetisi mengakibatkan nameplate terlihat kacau. Selain itu pada halaman cover BULETIN BINUS tampak adanya beberapa kelemahan dalam layout seperti penggunaan font pada judul-judul artikel dengan perlakuan yang berlebihan, jenis font yang terlalu banyak, kualitas gambar yang kurang baik serta cropping gambar yang tidak tepat. 


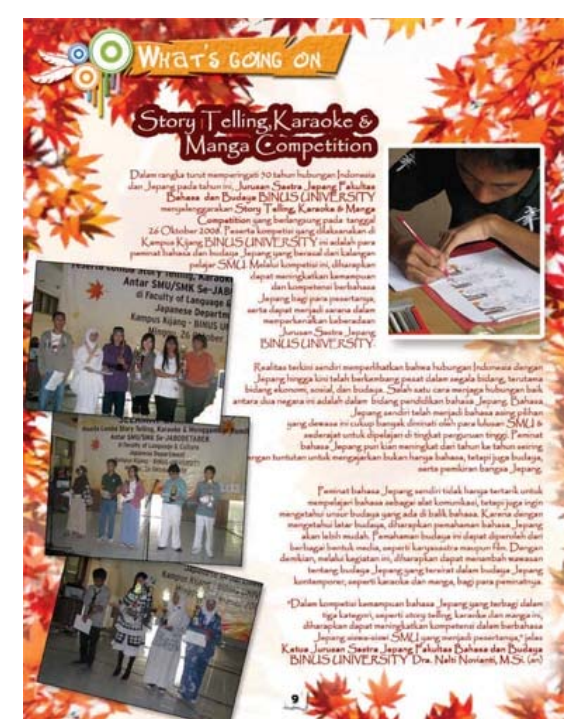

Gambar 5 Rubrik What's Going on



Gambar 6 Rubrik What's Going on

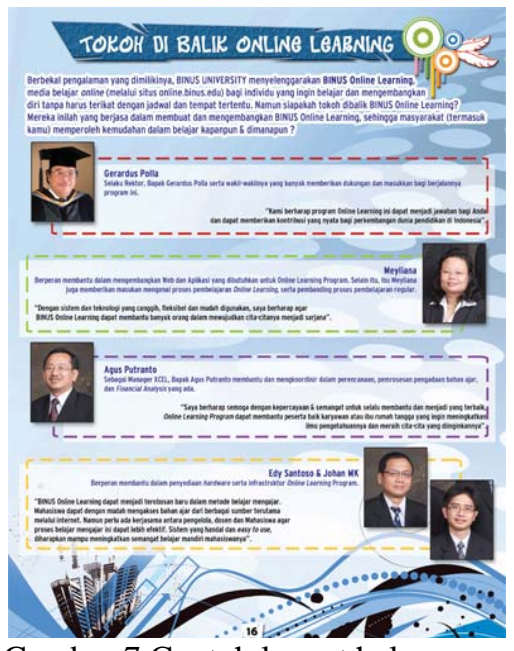

Gambar 7 Contoh layout halaman
Pada halaman di samping tampak bahwa ada kesalahan dalam pemilihan font dimana karakter yang ada pada tiap huruf cukup rumit sehingga ketika jenis huruf ini diaplikasikan pada teks menyebabkan tulisan tidak nyaman untuk dibaca, khususnya ketika teks ditampilkan secara all capitals. Hal ini ditambah lagi dengan pengaturan teks dengan komposisi rata kanan sehingga mengurangi kenyamanan dalam membaca. Ini dikarenakan kebiasaan membaca orang Indonesia dari kiri ke kanan, di mana ketika membaca sampai pada akhir baris di bagian kanan dan akan menyambung ke baris di bawahnya, orang akan cenderung mencari-cari baris yang dimaksud. Pengaplikasian warna jingga tua pada teks yang berukuran kecil cukup membuat mata lelah.

Pada contoh halaman ini terlihat bahwa pengaturan teks berukuran kecil dalam satu kolom panjang tidak sepatutnya diaplikasikan karena sangat melelahkan mata. Warna hijau yang diaplikasikan pada teks juga menambah ketidaknyamanan ketika dibaca. Besarnya headline yang lebih kecil daripada kickers secara hirarki kurang baik karena penampilan headline sebagai kepala artikel menjadi tertutup oleh kickers. Tulisan pada headline yang ditampilkan dengan diberi tambahan outline di sekitar judul, diletakkan di atas bidang bergambar susunan angka binari, membuat headline cenderung tertutup oleh elemen gambar dan tidak tampil menonjol.

Beberapa hal yang menjadi kelemahan pada layout halaman ini adalah penggunaan elemen estetis di bagian bawah halaman yang sesungguhnya bersifat pendukung infomasi ketika ditampilkan secara menonjol melalui bentuk dan warna yang kuat, berubah menjadi elemen visual utama. Selain itu secara sistematika penyusunan elemen layout, kickers dengan kalimat panjang tidak berfungsi untuk menjelaskan tema artikel namun lebih menyerupai headline yang dikemas dalam bentuk kickers. Body copy yang ditampilkan dengan diberi tambahan outline di sekitar tulisan, membuat body copy terlihat rumit dan hal ini mengurangi kenyamanan membaca. 

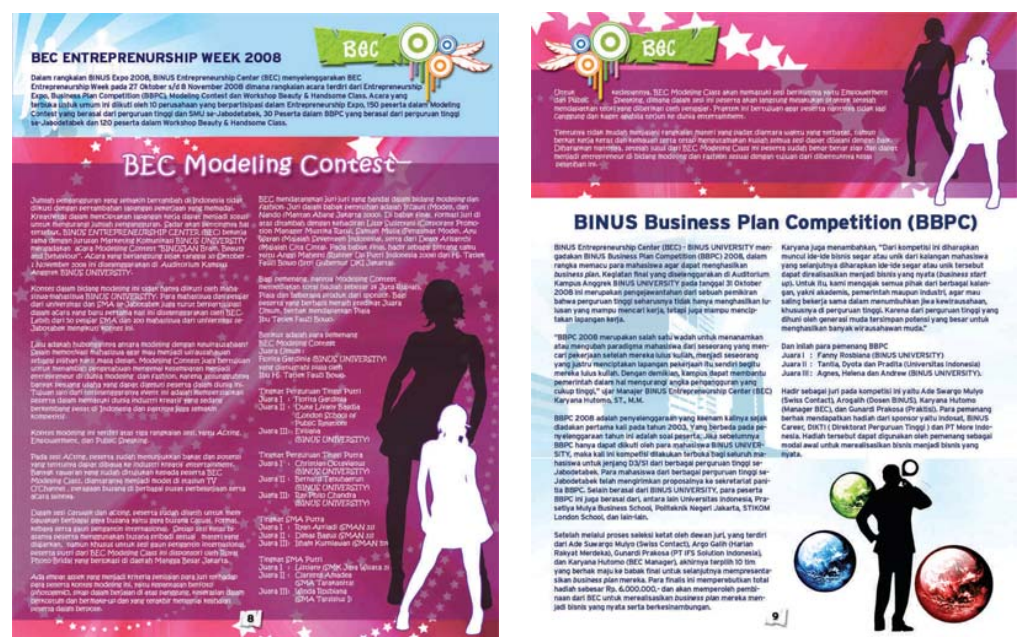

Gambar 8 Layout Halaman BEC

Pada contoh halaman ini terlihat bahwa pengaturan halaman untuk naskah yang panjang kurang cermat di mana pada artikel berjudul BEC Modeling Contest terjadi pemisahan halaman pada satu artikel. Hal ini sebaiknya dihindari dan sedapat mungkin artikel dapat diselesaikan pada halaman yang sama. Dari beberapa literatur Desain Komunikasi Visual, disebutkan bahwa ketika mendesain halaman editorial yang perlu diperhatikan adalah Profil target audience. Tampilan sebuah majalah mengenai gaya hidup untuk seorang wanita tentunya sangat berbeda dengan tampilan majalah yang berisi profil produk elektronik bagi sebuah perusahaan. Profil pembaca dapat diperoleh berdasarkan geografi, demografi atau psikografi (aktivitas, minat, opini).

Saat pekerjaan membuat layout dimulai, desainer dihadapkan pada artikel dalam bentuk lembaran naskah dengan yang panjang dan datar. Untuk itu dibutuhkan kepekaan seorang desainer dalam mengorganisasi sebuah artikel yang sebelumnya terlihat membosankan menjadi menarik untuk dibaca dengan menentukan bagian yang menjadi entry point, isi dan penutup serta bagian-bagian yang dapat mendukung daya tarik sebuah artikel. Maka artikel dapat dipecah menjadi beberapa bagian yang dikenal dengan elemen layout editorial. Elemen-elemen ini dengan fungsinya masing-masing saling bekerjasama satu dengan lainnya. Dengan memahami fungsinya masing-masing elemen ini menjadi modal bagi seorang desainer untuk mendesain layout editorial dengan baik. Elemen dalam layout editorial terdiri dari headline, deck, body copy, subhead, crosshead, pullquotes, caption, kickers, drop caps, running head, page number, dan lain sebagainya.

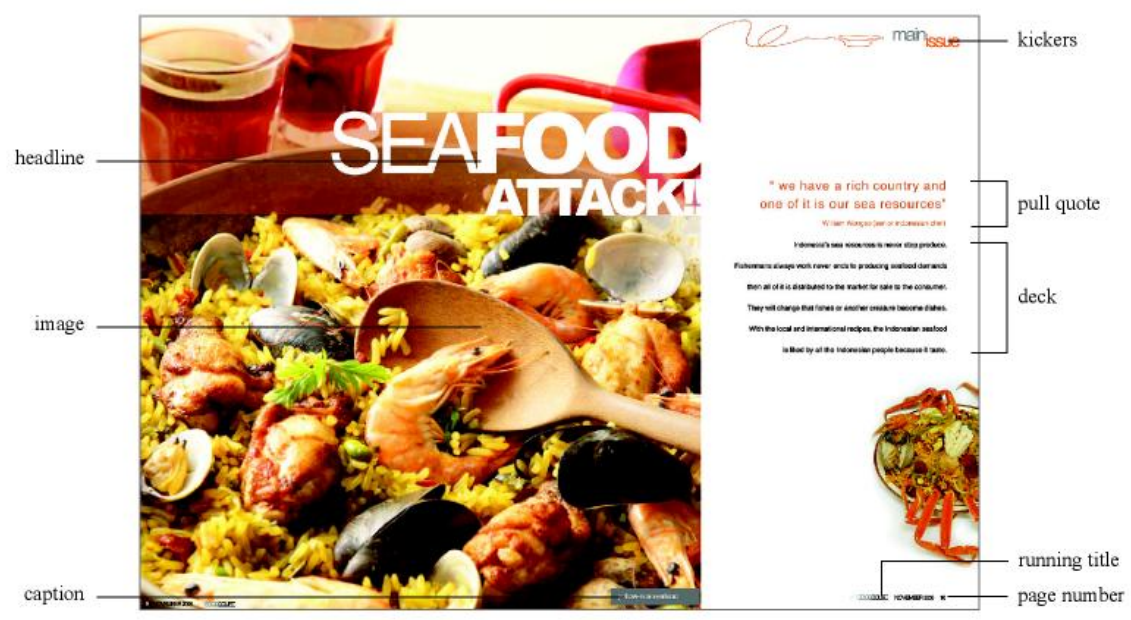

Gambar 9 Elemen Layout Editorial 


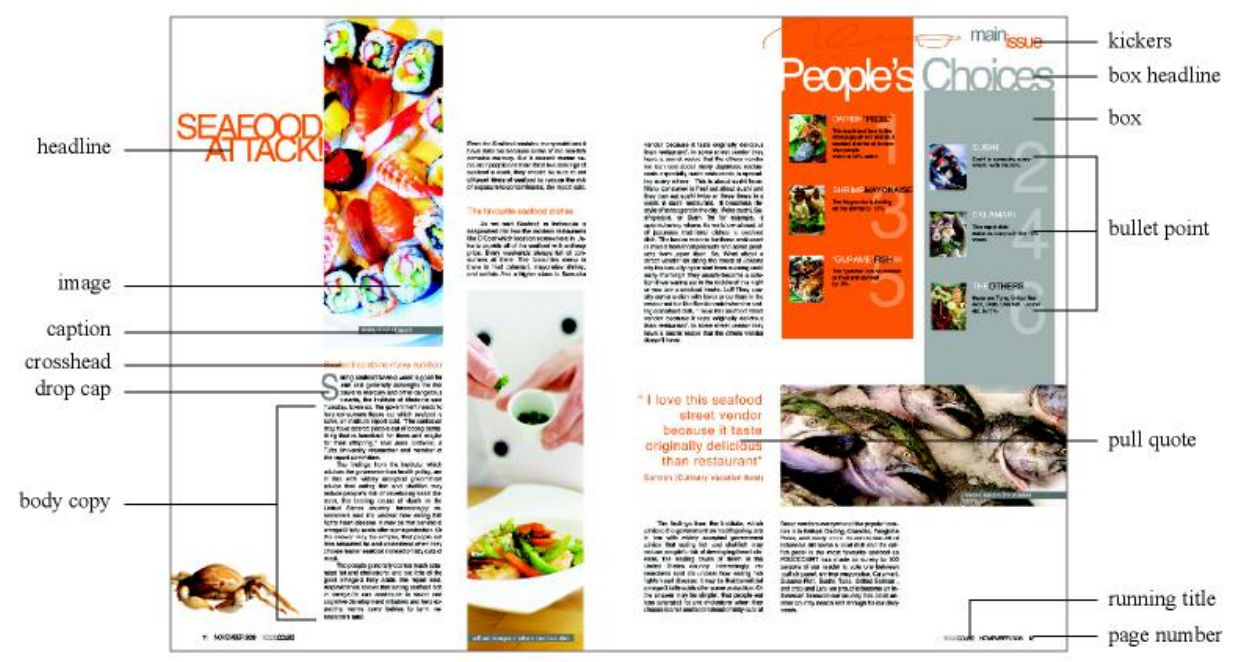

Gambar 10 Elemen Layout Artikel

Pastikan adanya clear space di sekitar headline sehingga mudah dibaca dan tidak bercampur dengan artikel lainnya. Naskah yang panjang dapat dipecah menjadi beberapa paragraf namun tetap dalam satu rangkaian yang menyatu sehingga tidak melelahkan mata. Manfaatkan penggunaan elemen layout untuk memperjelas bagian-bagian dari naskah. Perhatikan reading flow sehingga ketika kolom berakhir pembaca dapat langsung menyambung ke kolom berikutnya.

Tipografi merupakan elemen grafis yang sangat penting dari sebuah desain editorial karena informasi sebanyak 80\% disampaikan melalui tulisan. Pengaturan tipografi yang tepat sangat penting untuk diperhatikan. Desainer harus dapat memilih font yang benar-benar memiliki karakter huruf yang baik untuk kenyamanan pembacanya karena melalui bentuk dapat karakter-karakter huruf dapat diidentifikasi dengan cepat dan sehingga tulisan nyaman dibaca. Batasi penggunaan font maksimal 2 jenis font dan optimalkan penggunaannya dengan memanfaatkan family dari font tersebut. Terlalu banyak variasi akan menyebabkan tampilan terlihat berantakan. Untuk menyebut satuan ukuran huruf dikenal dengan istilah point size, disingkat pt. Umumnya untuk naskah (text type) digunakan 9 sampai $12 \mathrm{pt}$, lebih dari $14 \mathrm{pt}$ digunakan untuk display type (tulisan selain text type).

\section{abcdefghijklm abcdefghijklm}

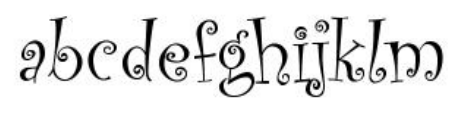
abedefghijklm

Gambar 11 Jenis Font
Umumnya untuk penggunaan pada naskah (text type) menggunakan font yang bentuknya sederhana dan termasuk ke dalam kelompok font serif (memiliki kait) dan sans serif (tidak memiliki kait) serta menghindari penggunaan font decorative (berhias) dan script (tulisan tangan). 


\begin{tabular}{|c|c|}
\hline Rowaw & планс \\
\hline $\begin{array}{l}\text { abcdefghijklm } \\
\text { abcdefghijklm } \\
\text { abcdefghijklm } \\
\text { abcdefghijklm } \\
\text { abcdefghijklm } \\
\text { abcdefghijklm }\end{array}$ & $\begin{array}{l}\text { abcdefghijk/m } \\
\text { abcdefghijklm } \\
\text { abcdefghijk/m } \\
\text { abcdefghijklm } \\
\text { abcdefghijk/m } \\
\text { abcdefghijk/m }\end{array}$ \\
\hline
\end{tabular}

Gambar 12 Jenis Huruf
Font merupakan sebuah jenis huruf, biasanya tersedia dalam beberapa jenis style yang disebut font family, seperti light, medium, bold, italic, bold italic, condensed, extended, small capitals, dan lain sebagainya.

Gambar adalah elemen penting dari sebuah halaman editorial. Gambar dapat menjadi pintu gerbang bagi pembaca untuk masuk ke dalam artikel yang hendak disampaikan. Oleh karena itu perlu pertimbangan yang matang baik dalam memilih gambar maupun cara menampilkannya. Gambar yang baik harus dapat mendeskripsikan artikel yang disampaikan secara cepat dan efektif, relevan dengan konteks yang disampaikan, memiliki makna yang dala, dan dapat mempengaruhi emosi pembacanya.Format dari gambar juga memiliki pengaruh dramatis, seperti halnya format gambar vertikal akan memberikan pemandangan yang unik di mana umumnya pandangan mata lebih banyak bergerak secara horizontal. Sedangkan format gambar horizontal dapat memberikan pandangan yang lebih luas sehingga informasi yang terangkum dalam gambar akan lebih kaya.

Melakukan zoom-in gambar adalah alternatif lain yang baik dilakukan untuk menampilkan detail. Selain itu gambar zoom-in juga dapat menambah daya tarik dimana orang dapat melihat sebuah visual yang jarang terlihat.Terkadang cropping perlu dilakukan apabila gambar yang ditampilkan terlalu banyak informasi yang sesungguhnya tidak relevan untuk ditampilkan. Oleh karenanya cropping perlu dilakukan secara hati-hati untuk menghindari adanya konteks yang hilang akibat terbuangnya gambar hasil cropping.Lakukan cut out pada gambar apabila gambar memang sudah dipersiapkan sebelumnya untuk hal tersebut, sehingga tidak menghilangkan konteks antara obyek dengan lingkungannya yang akhirnya dapat menimbulkan tanda tanya di benak pembaca. Hal penting lainnya yang perlu diperhatikan adalah proporsi yang harus terus dijaga dalam membesarkan atau mengecilkan ukuran gambar, jangan lakukan condensed (ditarik ke atas) atau extended (ditarik ke samping) pada gambar.Pastikan bahwa setiap gambar dilengkapi dengan caption untuk kenyamanan pembacanya.

Warna memiliki peran penting dalam sebuah editorial karena memiliki daya tarik dan warna berhubungan dengan emosi. Intensitas warna juga dapat mempengaruhi emosi pada pembaca, seperti kombinasi warna yang lembut, keras, kontras, masing-masing akan memberikan nuansa yang berbeda. Pada umumnya teks ditampilkan dalam warna hitam di atas bidang putih. Selain nyaman untuk dibaca, secara teknik cetak hal ini aman untuk dilakukan terutama pada teks dengan ukuran point yang kecil untuk menghindari hasil cetakan yang bergeser sehingga teks tidak nyaman ketika dibaca. Apabila teks ditampilkan di atas bidang warna, pastikan bahwa kombinasi yang dihasilkan tidak mengakibatkan efek optis pada mata, yaitu efek yang membuat teks menyilaukan mata sehingga melelahkan dan tidak nyaman untuk dibaca. Warna dapat diaplikasikan pada teks yang memiliki point size berukuran besar seperti headline, subhead, deck, quotes, crosshead, dropcaps selain untuk menambah daya tarik, memperjelas hirarki dan memperkuat konteks artikel.

Dari penjabaran di atas maka disusun sebuah usulan solusi kreatif melalui disiplin ilmu Desain Komunikasi Visual berupa saran penggunaan Master Page, Template dan Style Sheets. Sebagai editorial yang diterbitkan berulang, perlu adanya Master Page. Master Page adalah halaman yang berisi acuan-acuan desain dimulai dari ukuran margin, posisi nomor halaman, pengalokasian headline, subhead dan anatomi lainnya sampai gridyang merupakan alat bantu layout yang sangat bermanfaat yang membantu desainer dalam meletakkan elemen-elemen layout dan mempertahankan konsistensi dan kesatuan layout. Grid membagi halaman menjadi beberapa kolom tergantung kebutuhan dengan 
mempertimbangkan jumlah informasi dan nuansa visual yang akan ditampilkan. Untuk pengaplikasian grid pada halaman yang berulang, grid dapat dikembangkan menjadi grid system. Melalui eksplorasi pengaplikasian elemen layout pada grid system secara fleksibel akan menghasilkan layout yang menarik, variatif dan tidak kaku (monoton) namun tetap terstruktur, memiliki benang merah antara satu halaman dengan halaman lain dan tampil rapi.

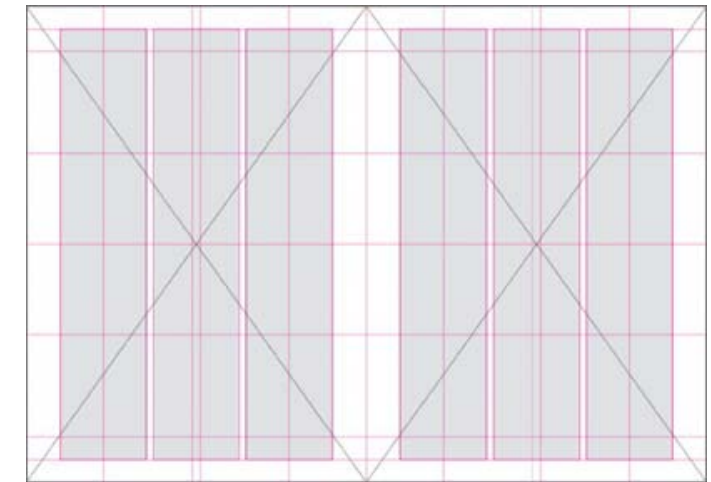

Gambar 13 Contoh Master Page
Master page dibuat 3 kolom pada masing-masing halaman, namun tidak tertutup kemungkinan apabila kolom disatukan sehingga pada grid telah disiapkan garis bantu pada tiap-tiap kolom sebagai acuan untuk penggabungan kolom.

Selain ada Master page, adanya template juga akan sangat membantu. Templates adalah halaman-halaman yang layout designnya sudah ditetapkan sebelumnya, berdasarkan pada kebutuhan yang berulang dan membentuk pola. Tentukan bagian yang akan menjadi entry point dengan memberikan penekanan melalui perlakuan pada font yang berbeda dengan yang lainnya. Pada templates sudah ditetapkan pemakaian font dan point size yang digunakan padaelemen layout editorialdan perlakuan pada gambar baik berupa elemen grafis, ilustrasi atau foto. Fungsi template selain untuk menjaga agar visual antar halaman tidak terlalu jauh berbeda, juga untuk mempercepat proses pembuatan layout karena dengan adanya template akan mempermudah pekerjaan layout.

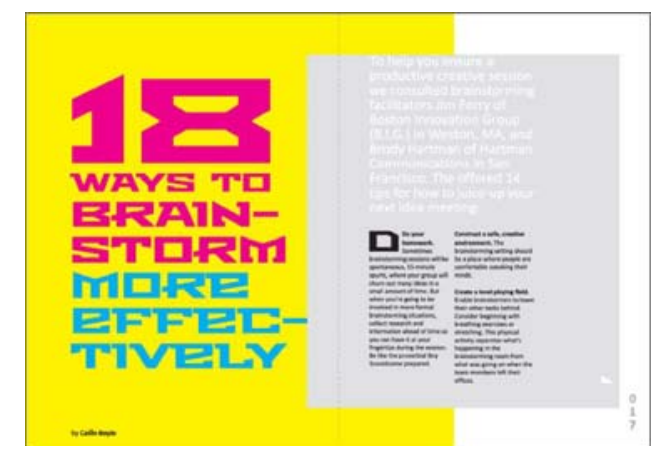

Gambar 14 Grid System pada Master Page

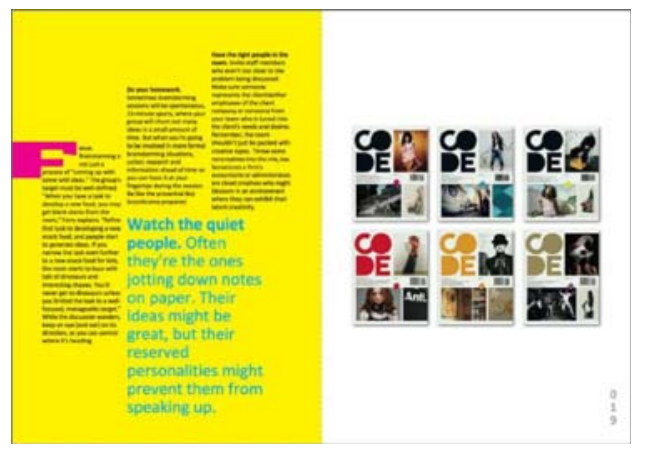

Gambar 15 Penempatan Quote dalam Grid Asimetris
Master page dibuat 3 kolom pada masing-masing halaman, namun tidak tertutup kemungkinan apabila kolom disatukan sehingga pada grid telah disiapkan garis bantu pada tiap-tiap kolom sebagai acuan untuk penggabungan kolom.

Pada Gambar 16, beberapa kolom digabungkan untuk penempatan quote. Body copy dibuat komposisi asimetris dalam grid untuk memperoleh variasi namun konsistensi layout secara keseluruhan dapat tetap terjaga. 


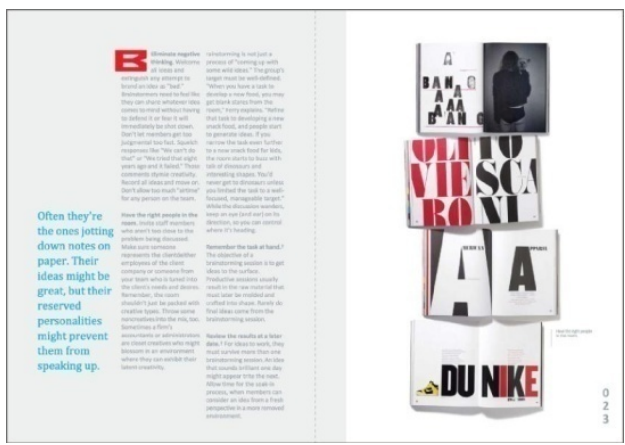

Dapat dilihat pada contoh template di atas bahwa kolom pertama dialokasikan untuk penempatan quote sedangkan body copy dapat mengisi dua kolom berikutnya. Pada halaman kanan diletakkan gambar dan disertai caption dengan noint size vano relatif keril aoar tidak

Gambar 16 Template Kolom Quote dan Body Copy

Berangkat dari penyusunan master page, templates dan style sheet, maka dapat ditetapkan elemen desain yang digunakan pada BULETIN BINUS berupa nameplate, tipografi, warna dan gambar yang dapat menjadi identitas visual Buletin. Nama Buletinyaitu BULETIN BINUS tentunya akan divisualisasikan dan dikembangkan menjadi nameplate, dengan pendekatan logotype. Logotype adalah sebuah kata yang ditampilkan melalui sebuah komposisi visual dengan menggunakan font tertentu, dikenali sebagai elemen penanda (signature). Nameplate tidak hanya harus unik namun juga harus dapat diaplikasikan di berbagai media komunikasi dalam berbagai cara dan ukuran.

Pilihlah font yang bentuknya sederhana dan termasuk ke dalam kelompok font serif (memiliki kait) dan sans serif (tidak memiliki kait) serta menghindari penggunaan font decorative (berhias) dan script (tulisan tangan) khususnya untuk penggunaan font pada naskah (text type).

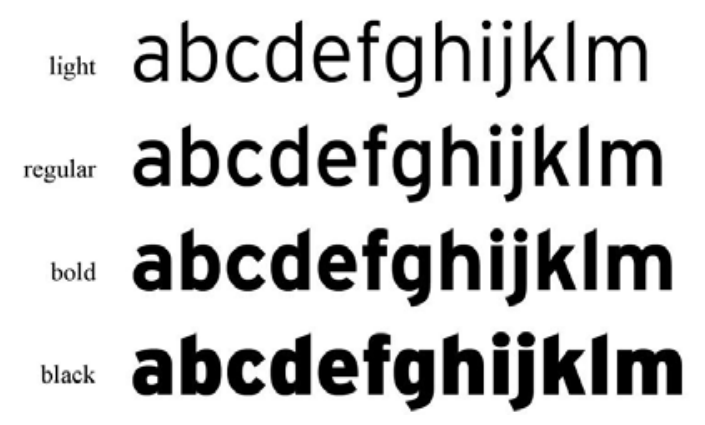

Gambar18 Font Interstate yang Digunakan BINUS University

BINUS University telah memiliki aset berupa official font bernama Interstate yang diciptakan dalam berbagai family (Gambar 1). Bentuk dari font ini sangat sederhana dan tegas, setiap karakter hurufnya mudah diidentifikasikan dengan cepat sehingga nyaman untuk dibaca. Manfaatkan family dari font tersebut untuk mempertegas hirarki pada elemen layout dan menciptakan variasi dengan tetap menampilkan visual yang sistematis dan rapi.

Sesuai dengan sifat Buletin sebagai media reportase, maka gambar-gambar yang digunakan sebagian besar menggunakan foto yang sifatnya dokumenter. Pada beberapa kasus apabila foto untuk gambar utama sulit didapat, maka sebagai gantinya dapat ditampilkan gambar ilustrasi yang sesuai dengan konteks pada artikel yang akan disampaikan. Untuk menjaga pencitraan agar tetap konsisten, maka melalui tampilan halaman BULETIN BINUS dalam penggarapan ilustrasinya perlu ditetapkan gaya ilustrasi. Hal ini dapat mendukung terbentuknya citra positif BINUS University. 
Sangat disarankan untuk memecah satu artikel yang panjang menjadi beberapa bagian dan dibuat hirarki yang jelas dengan memanfaatkan elemen layout editorial. Elemen-elemen ini dengan fungsinya masing-masing saling bekerjasama satu dengan lainnya. Untuk itu dibutuhkan kepekaan seorang desainer dalam mengorganisasi sebuah artikel yang sebelumnya terlihat membosankan menjadi menarik untuk dibaca.

Untuk menjaga kenyamanan membaca, teks ditampilkan dalam warna hitam di atas bidang putih atau apabila akan menggunakan warna, aplikasikan warna yang cenderung gelap di atas bidang berwarna terang. Warna dapat diaplikasikan pada teks yang memiliki point size berukuran besar seperti headline, subhead, deck, quotes, crosshead, dropcaps selain untuk menambah daya tarik, memperjelas hirarki dan memperkuat konteks artikel. Pemilihan warna dapat diarahkan kepada warna yang memiliki nuansa elegan namun tetap berjiwa muda, sesuai dengan lini usaha BINUS University sebagai sebuah institusi pendidikan tinggi yang mengedepankan teknologi, informasi dan komunikasi. Pada prinsipnya, desainer dihadapkan kepada seribu satu macam pilihan. Keputusan dapat dijatuhkan dengan mempertimbangkan profil BINUS University, visi, misi, value serta objective yang sudah dicanangkan sehingga visual yang dihasilkan dapat mewakili karakter BINUS University secara tepat.

\section{PENUTUP}

Buletin BINUS merupakan media komunikasi internal antara BINUS dengan Binusian, di mana menyampaikan informasi seputar kegiatan yang ada di lingkungan BINUS, prestasi dari Binusian serta artikel-artikel yang dapat meningkatkan pengetahuan dan wawasan para Binusian. Buletin ini mudah diperoleh karena didistribusikan melalui tempat-tempat yang yang menjadi pusat keramaian seperti ruang akademis, ruang jurusan, dan pusat-pusat kegiatan lainnya. Namun sayangnya tidak semua Binusian membaca Buletin BINUS karena kurang tertarik untuk melihat isinya.Hal utama yang menjadikan Binusian tidak tertarik untuk membaca Buletin BINUS adalah karena cover buletin kurang menarik sehingga tidak mendorong keinginan untuk membacanya.

Berdasarkan masukan dari Binusian yang membaca Buletin BINUS bahwa cara penyajian informasinya kurang nyaman, terlalu banyak teks dan artikel terlalu panjang sehingga kurang menghibur bahkan cenderung melelahkan. Hal ini diperkuat dengan hasil analisa penelitian mengenai kondisi Buletin BINUS, ditinjau dari sudut disiplin ilmu Desain Komunikasi.Selain kurang nyaman untuk dibaca, Buletin BINUS belum dapat mendukung terbentuknya citra BINUS University secara tepat. Oleh karenanya visual Buletin BINUS perlu diperbaiki dengan mempertimbangkan kepada profil pembacanya, isi dari artikel yang akan disampaikan, serta penggunaan elemen-elemen visual yang dapat membantu terciptanya citra BINUS University.

Dengan mempelajari profil pembacanya, Buletin BINUS dapat memperbaiki tampilannya sehingga mudah diterima oleh Binusian.Selain itu perlu adanya pertimbangan faktor kenyamanan dalam membaca.Hindari artikel yang terlalu panjang dan layout yang terlalu padat. Manfaatkan master page untuk mengaplikasikan elemen layout editorial seperti headline, subhead, deck, quotes, dan lainlain untuk menciptakan visual yang dinamis namun tetap rapi sesuai pencitraan yang diharapkan.

\section{DAFTAR PUSTAKA}

Frost, C. (2003). Designing for newspapers and magazines. London: Routledge.

Knight, C. (2003). Layout: Making it fit. Gloucester: Rockport Publishers. 
Rustan, S. (2008). Layout dasar \& penerapannya. Jakarta: Gramedia Pustaka Utama.

Samara, T. (2005). Publication Design Workbook. Beverly: Rockport.

Samara, T. (2005). Making and breaking the grid: A graphic design layout workshop. Beverly: Rockport.

Samara, T. (2007). Design elements: A graphic style manual. Beverly: Rockport.

Wheeler, A. (2003). Designing brand identity. New Jersey: John Wiley \& Sons. 